\title{
PENERAPAN CONTEXTUAL TEACHING LEARNING UNTUK MENINGKATKAN HASIL BELAJAR SISWA PADA MATA PELAJARAN KONTROL REFRIGERASI DAN TATA UDARA
}

\author{
Bhree A. Adityawarman ${ }^{1}$, Inu H. Kusumah², Ega T. Berman ${ }^{3}$ \\ Universitas Pendidikan Indonesia \\ Jl. Dr. Setiabudhi No. 229 Bandung 40154 \\ tahajjud21@gmail.com
}

\begin{abstract}
ABSTRAK
Penelitian ini bertujuan untuk memperbaiki proses pembelajaran dengan menerapkan model pembelajaran kontekstual untuk peningkatan hasil belajar dan aktivitas siswa. Penelitian ini dilakukan pada siswa SMKN 1 Cimahi program keahlian Teknik Pendingin dan Tata Udara kelas XI pada semester pertama tahun ajaran 2016/2017 dengan subjek penelitian berjumlah 35 orang. Metode penelitian yang digunakan adalah penelitian tindakan kelas. Teknik Pengumpulan data yang digunakan adalah observasi, instrument test, dan studi dokumentasi. Hasil penelitian menunjukan bahwa implementasi model pembelajaran kontekstual dapat meningkatkan hasil belajar dan aktivitas siswa pada program Teknik Pendingin dan Tata Udara. Implikasi dari penelitian ini adalah memberikan kesempatan pada guru produktif teknik pendingin untuk menerapkan dan mengembangkan penggunaan model pembelajaran.
\end{abstract}

Kata kunci: kontekstual, hasil belajar, aktivitas aiswa, refrigerasi

\section{PENDAHULUAN}

Kurikulum 2013 menganut pandangan bahwa pengetahuan tidak dapat dipindahkan begitu saja dari guru ke peserta didik. Peserta didik adalah subjek yang memiliki kemampuan secara aktif mencari, mengolah, mengkonstruksi, dan menggunakan pengetahuan. Hal ini sesuai dengan perubahan paradigma pembelajaran dari teacher centered menjadi student centered. Pembelajaran tidak lagi berpusat kepada guru, melainkan kepada peserta didik, sehingga guru harus mampu menguasai materi dan kelas (Didiek, 2015).

Model pembelajaran dipilih untuk meningkatkan pemahaman serta daya ingat belajar akan mata pelajaran yang akan disampaikan oleh guru. Proses pembelajaran tidak hanya berlangsung di dalam ruang kelas, tetapi bisa berlangsung di bengkel, laboratorium, lapangan, dan lain-lain. Model pembelajaran yang digunakan pada saat proses pembelajaran di ruang kelas belum tentu bisa diterapkan di dalam proses pembelajaran yang ada di dalam bengkel ataupun laboratorium. Oleh sebab itu, perlu adanya perubahan model pembelajaran yang lebih bermakna dan lebih memberdayakan siswa, sehingga dapat membekali siswa dalam menghadapi sebuah permasalahan hidup yang dihadapi sekarang

\footnotetext{
${ }^{1}$ Mahasiswa Departemen Pendidikan Teknik Mesin FPTK, UPI

${ }^{2}$ Dosen Departemen Pendidikan Teknik Mesin FPTK, UPI

${ }^{3}$ Dosen Departemen Pendidikan Teknik Mesin FPTK, UPI
} 
maupun yang akan datang. Untuk itu, model pembelajaran yang cocok untuk hal di atas adalah Pembelajaran Kontekstual atau Contextual Teaching and Learning (Hady, 2013).

Penerapan model pembelajaran CTL dalam pembelajaran Kontrol Refrigerasi dan Tata Udara (KRTU) melibatkan siswa untuk dapat berperan aktif dengan bimbingan guru, agar peningkatan kemampuan siswa dalam memahami konsep dapat terarah lebih baik. Pada saat pembelajaran berlangsung siswa diharapkan selalu bertanya orang sekitarnya untuk membantu siswa lebih meningkatkan pemahamannya mengenai KRTU.

\section{METODE PENELITIAN}

Penelitian ini menggunakan metode penelitian kelas (PTK) atau Class Action Research. PTK merupakan penelitian yang dilakukan oleh guru untuk memperbaiki proses pembelajaran di kelas dengan jalan merefleksikan hasil pengamatan yang didapatkan selama penelitian ke dalam bentuk tindakan. Penelitian ini dilaksanakan dengan tiga siklus dengan masing-masing siklus ada tiga tahapan, yaitu rencana, tindakan dan refleksi.

\section{HASIL PENELITIAN}

Hasil belajar siswa merupakan penilaian kemampuan siswa terhadap materi yang telah diajarkan. Hasil belajar digunakan untuk melihat kemampuan siswa sebelum dan sesudah dilakukan treatment berupa model pembelajaran contextual teaching learning. Tabel 1 menunjukan rata-rata nilai pre test dan post test setiap siklus dan rata-rata siswa lulus KKM dan tidak lulus KKM.

Tabel 1. Rata-Rata Nilai Pre Test dan Pos Test Siswa

\begin{tabular}{cccc}
\hline Siklus & Pre Test & Pos Test & Rata-Rata Kenaikan Nilai \\
\hline Siklus I & 38,53 & 66,2 & 27,67 \\
Siklus II & 37,08 & 73 & 36,0 \\
Siklus III & 40,9 & 76,53 & 35,63 \\
\hline
\end{tabular}

Tabel 2. Frekuensi Kelulusan Siswa

\begin{tabular}{ccccc}
\hline Siklus & Lulus KKM & Persentase & Tidak Lulus KKM & Persentase \\
\hline Siklus I & 7 & $21,8 \%$ & 25 & $78,12 \%$ \\
Siklus II & 13 & $37,14 \%$ & 22 & $62,86 \%$ \\
Siklus III & 21 & $61,76 \%$ & 13 & $38,2 \%$ \\
\hline
\end{tabular}

Peningkatan hasil belajar siswa pada siklus I dengan rata-rata kenaikan yang masih rendah (Tabel 2) siswa yang lulus KKM sebanyak 21,8\% dan 78,12\% siswa belum lulus KKM. Penyebab rendahnya hasil belajar siswa karena siswa masih adaptasi dengan lingkungan dan materi yang baru serta model yang digunakan. Sementara pada siklus II 
rata-rata nilai mengalami peningkatan dan siswa yang lulus KKM juga mengalami peningkatan sebanyak $37,14 \%$ dan $62,86 \%$ siswa belum lulus KKM. Siklus II sudah terlihat ada peningkatan karena siswa sudah mulai terbiasa dengan materi dan model pembelajaran yang digunakan. Selanjutnya pada akhir siklus III rata-rata kenaikan mengalami peningkatan kembali dan siswa yang lulus KKM juga mengalami peningkatan menjadi $61,76 \%$ dan $38,2 \%$ siswa belum lulus. Sehingga dapat dikatakan bahwa terjadi peningkatan hasil pada setiap siklusnya. Rata-rata presentase aktivitas belajar siswa dengan menerapkan contextual teaching learning, yaitu: siklus I aktivitas siswa sebesar 58\%, siklus II aktivitas siswa sebesar 63,8\%, dan siklus III aktivitas siswa sebesar 69,4\%,

Aktivitas belajar siswa secara umum mengalami peningkatan dari setiap siklusnya, walaupun masih dalam kriteria yang sama tiap siklusnya. Peningkatan tersebut menunjukan bahwa semakin baiknya aktivitas belajar siswa dengan menggunakan model CTL. Peningkatan ini terjadi karena adanya evaluasi setelah kegiatan setelah kegiatan pembelajaran di kelas selesai. Evaluasi ini dilakukan oleh peneliti bersama observer untuk memperbaiki kekurangan yang terjadi pada saat penerapan model CTL di kelas pada setiap siklusnya.

\section{PEMBAHASAN}

Hasil penelitian menunjukkan bahwa dengan menggunakan CTL dapat mempengaruhi hasil belajar siswa. Hasil belajar siswa menggunakan model CTL terlihat setiap siklus mengalami peningkatan. Peningkatan hasil belajar ini terjadi karena pada penerapan model CTL memiliki beberapa karakteristik, yaitu: berpusat pada siswa, menghubungkan antara teori dan kehidupan nyata siswa, dan membangun pengetahuan secara berkelompok. Sehingga siswa dapat mempelajari materi yang diberikan dan setiap anggota kelompok akan kerjasama untuk mengidentifikasi materi yang ada dan bersamasama (Smith, 2010). Setelah itu menghubungkan materi yang mereka peroleh dengan proses praktikum.

Siklus I menunjukkan siswa yang mengerjakan soal pre test tidak ada yang nilainya berada di atas KKM. Setelah diterapkan model pembelajaran CTL dan dilakukan post test, nilai siswa meningkat. Dapat dilihat pada gambar 2, rata-rata nilai pre test dan post test meningkat, dari 38,53 menjadi 66,2. Siswa yang nilainya berada diatas KKM (> 75) berjumlah 7 orang, dengan nilai N-Gain sebesar 0,44 (kriteria sedang). Jumlah siswa yang lulus masih sedikit, karena prosedur pelaksanaan model CTL kurang tersampaikan dengan jelas oleh guru kepada siswa. Sehingga komponen-komponen CTL belum terlaksanakan 
dengan baik. Pada pembahasan materi pada setiap kelompok terlalu sulit, karena sumber buku pembelajaran masih sedikit.

Siklus II menunjukkan siswa yang mengerjakan soal pre test tidak ada yang nilainya berada di atas KKM. Setelah diterapkan model pembelajaran CTL dan dilakukan post test, nilai siswa meningkat. Dapat dilihat pada gambar 2, rata-rata nilai pre test dan post test meningkat, dari 37,08 menjadi 73 . Siswa yang nilainya berada diatas KKM (> 75) berjumlah 13 orang, dengan nilai N-Gain sebesar 0,56 (kriteria sedang). Jumlah siswa yang lulus sudah meningkat dibandingkan siklus I, karena siswa-siswa sudah mulai beradaptasi dengan model pembelajaran CTL dan komponen-komponen CTL sudah mulai terlaksanakan dengan baik. Peran guru dalam membimbing kelompok sudah baik tetapi belum maksimal. Pada saat proses diskusi kelompok sudah terlaksana lebih baik daripada siklus I, terlihat dari kerjasama siswa untuk menguasai materi diskusi yang diberikan oleh guru.

Siklus III menunjukkan siswa yang mengerjakan soal pre test tidak ada yang nilainya berada di atas KKM. Setelah diterapkan model pembelajaran CTL dan dilakukan post test, nilai siswa meningkat. Dapat dilihat pada gambar 2, rata-rata nilai pre test dan post test meningkat, dari 40,9 menjadi 76,53. Siswa yang nilainya berada diatas KKM (> 75) berjumlah 21 orang, dengan nilai N-Gain sebesar 0,60 (kriteria sedang). 75) berjumlah 13 orang, dengan nilai $\mathrm{N}$-Gain sebesar 0,56 (kriteria sedang). Jumlah siswa yang lulus sudah meningkat dibandingkan siklus II, karena siswa-siswa sudah mulai beradaptasi dengan model pembelajaran CTL dan komponen-komponen CTL sudah mulai terlaksanakan dengan baik. Pada proses pembelajaran motivasi dan antusias siswa cukup tinggi.

Hasil penelitian yang telah dilakukan menunjukkan peningkatan nilai hasil belajar siswa pada setiap siklusnya karena model CTL diyakini sangat cocok untuk pembelajaran ilmu teknik. Karena metodologinya mengaitkan antara materi yang diajarkannya dengan situasi dunia nyata siswa, dapat mendorong siswa membuat hubungan antara pengetahuan yang dimilikinya dengan penerapannya dalam kehidupan mereka sebagai anggota masyarakat. Peningkatan hasil belajar siswa diukur menggunakan $\mathrm{N}$-Gain yang diperoleh dari nilai pre test dan post test siswa. $\mathrm{N}$-Gain yang diperoleh setiap siswa kemudian dijumlahkan dan dirata-ratakan untuk mendapat rata-rata $\mathrm{N}$-Gain. $\mathrm{N}$-Gain yang diperoleh pada siklus I sampai siklus III mengalami peningkatan dan berada pada kriteria sedang. Peningkatan $N$-Gain juga diikuti dengan perubahan hasil belajar siswa yang di ukur berdasarkan KKM dan hasil belajar siswa berdasarkan KKM meningkat pada setiap 
siklusnya. Peningkatan hasil belajar ini dipengaruhi dengan adanya perbaikan proses pembelajaran pada setiap siklusnya. Perbaikan yang dilakukan yaitu dengan cara meningkatkan faktor-faktor yang mempengaruhi hasil belajar, baik itu faktor internal maupun eksternal. Guru berusaha untuk lebih dapat menarik minat dan memotivasi siswa sebagai upaya meningkatkan faktor internal. Sementara itu, upaya peningkatan faktor eksternal yang dilakukan adalah berupa penciptaan lingkungan yang kondusif, perencanaan pembelajaran yang matang, serta memberikan media pembelajaran yang mendukung dan menarik. Upaya tersebut membuat hasil belajar siswa meningkat dari kategori dari belum lulus menjadi lulus. Peningkatan hasil belajar ini sesuai dengan tujuan penerapan model CTL atau dengan kata lain penerapan model CTL dapat meningkatkan hasil belajar siswa.

Melihat peningkatan hasil belajar siswa selama tiga siklus diatas maka akhir dari proses belajar adalah perolehan suatu hasil belajar siswa kemampuan-kemampuan yang dimiliki oleh siswa setelah ia menerima pengalaman/interaksi belajarnya. Disimpulkan bahwa hasil belajar merupakan proses kegiatan belajar-mengajar yang membawa perubahan dan bentuk tingkah laku seseorang. Ketika ada kenaikan nilai belajar siswa membuktikan adanya peningkatan kemampuan dan pemahaman dari proses belajarmengajar yang telah dilaksanakan sehingga membawa sebuah perubahan kepada siswa dari bentuk tingkah laku dan nilai yang diperoleh siswa.

Penerapan model CTL selain dapat meningkatkan hasil belajar siswa, aktivitas belajar siswa juga mengalami perubahan, dapat dilihat pada Gambar 3. Siswa harus mengikuti kegiatan pembelajaran di kelas berdasarkan rencana yang telah disusun. Perencanaan aktivitas belajar siswa meliputi membaca, bertanya, menjawab, mendengarkan dan menulis. Aktivitas belajar siswa siklus I berada pada kriteria tinggi, meskipun pada kriteria tinggi, akan tetapi aktivitas belajar siswa belum sesuai dengan penerapan model CTL. Penyebabnya karena siswa masih melakukan penyesuaian dengan metode yang sedang diterapkan. Berdasarkan hasil penelitian, aktivitas belajar siklus II berada pada kriteria tinggi. Aktivitas belajar siswa mengalami peningkatan dibandingkan siklus I. aktivitas belajar siswa siklus II sudah mengarah kepada materi pembelajaran dan siswa sudah mulai terbiasa dengan model pembelajaran yang digunakan. Selanjutnya siklus III, aktivitas belajar siswa kembali mengalami peningkatan, aktivitas belajar siswa siklus III berada pada kriteria tinggi.

Salah satu prinsip dari CTL adalah konstruktivisme (Trianto, 2007). Penekanan teori konstruktivisme pada proses pembelajaran adalah untuk menemukan teori atau pengetahuan, yang dibangun dari realitas lapangan. Peran guru dalam pembelajaran 
menurut teori konstruktivisme adalah sebagai fasilitator atau moderator. Teori belajar kognitif Piaget menyatakan bahwa ilmu pengetahuan dibangun dalam pikiran seorang anak dengan langkah-langkah yang telah direncanakan (Hsiung, Lin, \& Lai, 2011). Berdasarkan teori tersebut akan berpengaruh terhadap aktivitas siswa dalam proses pembelajaran yang menerapkan model CTL. Dapat dilihat dengan meningkatnya aktivitas pembelajaran siswa setiap siklusnya.

Peningkatan ini terjadi karena siswa sudah terbiasa dengan model pembelajaran yang diterapkan, siswa sudah terfokus kepada materi. Berdasarkan hasil pengamatan yang dilakukan, jelas bahwa model CTL dapat meningkatkan aktivitas belajar siswa. Keberhasilan penerapan model CTL untuk meningkatkan hasil belajar siswa dan aktivitas dipengaruhi suasana kelas yang mendukung terlaksananya kegiatan pembelajaran serta kegiatan siswa telah dikondisikan dan terarah sesuai dengan rencana yang telah disusun.

\section{KESIMPULAN}

Kesimpulan penelitian ini menunjukkan bahwa penerapan contextual teaching learning pada mata pelajaran kontrol refrigerasi dan tata udara dapat meningkatkan hasil belajar siswa. Peningkatan hasil belajar pada setiap siklusnya ditunjukan dengan peningkatan nilai rata-rata $N$-Gain siswa pada setiap siklusnya. Rata-rata nilai $N$-Gain siswa mengalami peningkatan dari siklus I hingga siklus III dan berada pada kriteria sedang. Hasil belajar setiap siklus penelitian tindakan kelas ini dapat meningkat karena terjadi perbaikan proses pembelajaran yang dilakukan pada setiap siklus. Model contextual teaching learning dapat digunakan karena dapat meningkatkan aktivitas belajar siswa dan berdampak pada pemahaman kognitif dan psikomotor siswa meningkat pada mata pelajaran Kontrol Refrigerasi dan Tata Udara.

\section{REFERENSI}

Didiek, P. (2015). Kendala-Kendala Implementasi Kurikulum 2013 Di SMKN 3 Buduran dan Solusinya. Jurnal Pendidikan Teknik Mesin Unesa. (4) 2, hlm. 21-28.

Hady, A. (2013). Penerapan Model Pembelajaran Kontekstual pada Praktikum Sistem Kelistrikan Body Otomotif untuk Meningkatkan Hasil belajar Mahasiswa d3 Teknik Mesin Unesa. Jurnal Pendidikan Teknik Mesin Unesa. (1) 2, hlm. 86-92.

Hsiung, L., Lin, M., \& Lai, M. (2011). A New Approach of Image Processing Teaching by Gagne Learning Conditional Theory. International Journal of Information and Education Technology. (1) 1. 
Smith, B. (2010). Instructional Strategies in Family and Consumer Sciences: Implementing the Contextual Teaching and Learning Pedagogical Model. Journal of Family \& Consumers Science Education. (28), 1.

Trianto. (2007). Model-Model Pembelajaran Inovatif Berorientasi Kontruktivistik. Jakarta: Prestasi Pustaka. 